\title{
The Synergy Transportation
}

\author{
V.Vlčková* \& Z. Votruba \\ Both authors are with the Faculty of Transportation Sciences, Czech Technical University in Prague, Czech \\ Republic \\ *Corresponding author: vlckova@fd.cvut.cz
}

DOI: $10.2478 / \mathrm{v} 10158-010-0024-\mathrm{y}$

\begin{abstract}
Paper reflects the aspiration to denominate the relation between transportation and fields of environmental and nature phenomena, following and having respect for the principles of sustainable development. Systems knowledge and methodologies are used: Systems approach; methodologies of synergy and principles of sustainable development. The Theory of Production Function is extended to tackle these problems.
\end{abstract}

KEYWORDS: Transportation as a science, systems approach, synergy, sustainable development, production function.

\section{INTRODUCTION TO THE TERNARY RELATION: TRANSPORTATION - HUMAN SOCIETY - SUSTAINABLE DEVELOPMENT}

The primary factor of this study is the aspiration to denominate the relation between the branch of transportation \& Environmental Sciences, following and having respect for the principles of Sustainable Development. A definition of this relation can consequently inspire a set of methodologies, methods, technologies, and techniques of transportation to be used and enhance their Problem Solving abilities. To reach this goal:

- firstly, the formulation of theses and the attributes of branch of transportation should be completed (Vlček, 1996),

- secondly a set of Systems Knowledge and methodologies are to be used (Systems approach; a body of knowledge on synergy) (Veselý, 2005; Vlček, 1984; Vlček, 1999; Vlček \& Petr, 1983);

- tertio principles of sustainable development, influencing the perception of the application area of the branch of transportation, are to be taken into account (EC, 2003; Mezrrický et al., 2005; Míchal, 1976; Míchal, 1994; ČR, 2004; ÚÚR, 2000).

The branch of transportation is in the role of the object of research. Systems Approach (Vlček, 1999), a set of tools of Systems Engineering and topics of studies of synergy are sets of methodologies used, while terminologies, methodic tools and the concept of sustainable development are perceived as an application environment, as peripheral surroundings of the process of this research. Transportation as a science is fundamentally analyzed in (Vlček, 1996). It is sketched out as a conceptual abstract base for the research of transportation features. A fulfillment of the four basic prerequisites of the concept of transportation science is completed with a primary sketch of the formalization of the basic effects of transportation - 
Production Functions of Transportation (Vlček, 1999). The effects from the 1 st to the $5^{\text {th }}$ degree of formulated functions are explained. In (Vlček, 1996) presented set of considerations and argumentations, including pertinent terminology, is thoroughly used within this paper.

Besides the Systems Approach (Vlček, 1999), a set of tasks solving practices based on the body of Systems Engineering - see (Veselý, 2005; Vlček, 1984; Vlček, 1999; Vlček \& Petr, 1983), is thoroughly utilized (for example for an efficient capture of external relationships and connections with the other branches and, consequently, with the whole of the anthropogenic sphere). The notion of sustainable development (as well as its terminology, methodology, semantics, environment i.a. described in (Č́R, 2004)) at a relatively high rate conforms to the mechanisms and procedures of a Systems approach (Vlček, 1999) to the complex tasks' solutions. It is therefore possible to use it in a similar manner. Unifying three apparently unique branches - economy, environmental science, and social community responsibility - there is an aim to perceive and to implement for any tasks the relationships with the surroundings, and to respect feedback impacts as well. In other words - it is necessary to formulate and to solve any transportation task in the large scale with all significant connections. Thus it is also plausible to forestall projecting oversized or unnecessarily complicated transportation systems that have not adequately taken into account both the local and global consequences, the future of energy sources, and social impacts. This aspect of sustainability has de facto tight links with an old problem within the economy, i.e., an appropriate evaluation and a setting of externalities.

\section{METHODOLOGICAL COMPONENTS}

\subsection{TRANSPORTATION AS A SCIENCE}

In the object of transportation four degrees of production function are recognized (Vlček, 1996; Vlček, 1999).

The first degree of production function, $\mathrm{E}=\mathrm{f}(\operatorname{Inv}$, Mat, $\check{C} \mathrm{l})$, is entitled as the:

i. technology function with parameters Inv (input demand), Mat (material) and $\check{C}$ l (man);

ii. economized function being enhanced with parameter Pe (finance);

iii. administration function being upgraded by parameter Adm (administrative); and

iv. informatized function being further upgraded with the additional parameter Inf (informatics);

finally the degree of the informatized production function is obtained:

$$
\mathrm{E}^{\cdots}{ }^{\prime \prime}=\mathrm{f}^{\prime}{ }^{\prime}(\text { Inv, Mat, } \check{C} \mathrm{l}, \mathrm{Pe}, \mathrm{Adm}, \mathrm{Inf}) \text {. }
$$

For these four degrees of the production function there are five verbally expressed resulting frames for axiomatic prediction of their effects in (Vlček, 1996; Vlček, 1999). While the effect of the 1st degree is based on a mutual connection of two function participants, the effect of the 2 nd degree includes a relationship between connections of the 1 st degree (so the sequence of unique relation pairs is generated), the effect of the 3rd degree is generated by the connection of relations among participants at the "plane" of the lower degree production function, etc. The effect of the 5th degree implements therefore "space", and the fourth imaginary dimension - time. This degree of the production function can be used only in very complicated tasks, for example in strategies and alliances of economic and political supersystems. 
In further text we will utilize the way of reasoning and the formulation of the production function from (Vlček, 1996; Vlček, 1999), accepting the validity of the hypothesis that "enhancement of an effect is possible by extending the dimensionality of space, where the production function of the previous degree is valid".

Then it is advisable within this context to bring in the formula of an even higher degree:

$$
\mathrm{E}^{\cdots}{ }^{\prime \prime}=\mathrm{f}^{\cdots \cdots}(\mathrm{Inv}, \mathrm{Mat}, \mathrm{C} \mathrm{l}, \mathrm{Pe}, \mathrm{Adm}, \mathrm{Inf}, \mathrm{D}),
$$

reflecting the effect of sustainable development $\mathrm{D}$, as well.

\subsection{The Systems approaches - synergy}

The foundations for a Systems approach (Vlček, 1984; Vlček, 1999; Vlček \& Petr, 1983) are based on a respect for a reciprocity of parts, on an interface - on a structure and behavior of systems, on the emergence of synergy (Veselý, 2005) in Complex Hybrid Systems or Alliances. Defined Systems tools, as well as systems management, are based at first on Systems analysis, and second on Systems synthesis (Vlček, 1984; Vlček, 1999; Vlček \& Petr, 1983). Both branches are simultaneously objects of interest, as well as tools and instruments for studying target tasks of Synergy, i.e., the multiplicative result of cooperation and collaboration of Systems parts. The very beginning of this study is (Veselý, 2005) the recognition, then definition of Systems alliance, which shows the creation of a system alliance via interactions, both internal and external (vide system analysis tasks on an interface in (Vlček, 1984; Vlček, 1999; Vlček \& Petr, 1983)). The features of it are defined by synergy effects as a high-level internal quality emerging from the attributes of communicating parts. This synergy effect can be reflected - in the sense of production functions referred in (Vlček, 1996; Vlček, 1999) - as a specific form of an added value, as an origin of new value, what could be called an added output, generated from the efficiency of a function relationship of interacting parts of the System as a whole.

The branch of transportation (Vlček, 1996; Vlček, 1999) in concepts of the effects of the 4th and 5th grades is, (in the sense of thesis (Veselý, 2005)), a sufficiently complicated Hybrid System, or an Alliance of Systems, in which the synergy could emerge.

Nevertheless, the synergy is also a key factor if the concept of sustainable development is taken into account, as the study of the correspondence of parts of the system, as well as its external relations, is based on the research of synergy effects. This is why this research is carried out on the utilization of functions which implement in their arguments parameters of nature and living environment (or - in other words - all three linchpins of sustainable development). Therefore, synergy seems to be a proper tool for the further study and creation of the basic concepts of transportation as well.

\subsection{Sustainable development}

Three basic linchpins of the concept of sustainable development - economy, ecology and social responsibility - create, without doubt, a complex environment of human civilization (Míchal, 1976; Míchal, 1994; ÚÚR, 2000; WCED, 1987; ČR, 2004; ČR, 2006); within this framework input parameters are created and output values of production functions have an impact on them; this is why they have to be reflected in production functions.

A short summary of the content of the term sustainable development (Míchal, 1976; Míchal, 1994; ÚÚR, 2000; WCED, 1987; ČR, 2004; ČR, 2006) is feasible with references to the apparatus of informatics, or knowledge engineering (Vlček, 1999), i.e., simple data, 
items about nature and living environment. It could result in environmentally characterized information, or possibly implied (transitive) information up to knowledge, not only on a state of (eco)systems, but above all on the reasons and consequences of these states. Subsequently their qualified predictions lead to their systemization and arrangement into a System of principles and institutes of community's behavior, as well. Not only environmentally oriented, but also technocratic, branches of human activities study the specifications and limits of a balance between development and the further progress of (eco)systems (Míchal, 1976; Míchal, 1994; ÚÚR, 2000; WCED, 1987; ČR, 2004; ČR, 2006). This is the sense of declarations of the sustainability of the conceivable evolution of a civilized human society (Míchal, 1976; Míchal, 1994; ÚUUR, 2000; WCED, 1987; ČR, 2004; ČR, 2006). In the most frequent definition of the concept of sustainable development (EC, 2003; Mezřický et al., 2005; Ŕíha, 2001; UN, 1992; UN-ECE, 2002, ÚÚR, 2000), it is stated, that sustainable development meets the needs of the contemporary generation, without threatening the living conditions for future generations. In other words it is a balanced relationship of:

- conditions for an acceptable natural environment,

- for economic development, and

- for the social cohesion of inhabitants.

The three linchpins of sustainable development, resulting from this definition (EC, 2003; Mezřický et al., 2005; Ř́ha, 2001; UN, 1992; UN-ECE, 2002, ÚÚR, 2000), should be in mutual balance. By now (vide in (ČR, 2004)) social and economic views are applied rather intuitively, "practice" predominates more often, which results in short-term views, corresponding with political priorities, relating to periods of an electoral term and to criteria of a free market economy, and regulated by the minimization of economic investment return time.

The ecological linchpin implements the thesis that for continuing the physical sustainability of the evolution of the physical living environment the material and energy stream must fulfill three conditions (EC, 2003; Mezřický et al., 2005; Ř́ha, 2001; UN, 1992; UN-ECE, 2002, ÚÚR, 2000):

a) the intensity of renewable resources usage is lower than the rate of their regeneration;

b) the intensity of nonrenewable resources usage is lower than the rate of the introduction of their sustainably renewable substitutes;

c) the intensity of pollution is lower than the assimilation capacity of the living environment.

However, up until now the economic increase, and the social enrichment enabled by this increase, has been consuming non-renewables, especially energetic resources. The same is valid for land usage for building and production activities (WCED, 1987; ČR, 2006; С̆R, 2006).

The social linchpin postulates that in order to attain social sustainability a combination of population, funds and technologies has to be composed in such a way that the living standard has to be sufficient and consensual for every individual. The so-called Index of Human Development (United Nations Development Program, UNDP) is defined as a multiple index (EC, 2003; Mezřický et al., 2005; Ř́ha, 2001; UN, 1992; UN-ECE, 2002, ÚÚR, 2000), compounded of three particular indicators with the same weight:
a) life expectancy at birth;
b) an access to education (a proportion of the number of literate adults to an average length of school education);
c) GDP per capita. 
The economic linchpin reflects an economic increase. From the point of view of sustainability it is possible to consider the trend, in which an economic increase is reached by:

a) intensification,

b) technological or organizational innovation,

c) higher quality and human work efficiency (not by the further exploitation of natural resources).

It concerns the development and use of technologies which are environmentally friendly, as well as less energy usage and lower consumption of raw materials and removing environmental pollution from the past.

More generally:

- The law of conservation of energy / matter / information correlates with an ecology linchpin.

- The principle of entropy increase could be related to an economy linchpin.

\section{THE FORMULATION OF THE RELATION: TRANSPORTATION - SYNERGY - SUSTAINABLE DEVELOPMENT}

\subsection{The fifth degree of production functions}

An implementation of the sustainable development problems is, in fact, possible in two virtual dimensions:

I. "horizontally" as a completion of a further argument into the formula of a production function;

II. "vertically" as a certain specification of the argument D itself in the basic formula of production function. Consequently, we can study sustainable development as a specific feature of argument $\mathrm{D}$, therefore we can speak about sustainable transportation.

In the first case we come to the discussion of a question of transportation as a science, particularly whether it is possible to understand sustainable development itself as a science, then - in analogy with formal notation in (Vlček, 1996) - to introduce (if we detach an orientation towards transportation):

A sustainable production function, leading to full-bodied reflection of sustainable development conditions in the form:

$$
\mathrm{E}^{\cdots \cdots}=\mathrm{f}^{\cdots \cdots}(\text { Inv, Mat, } \check{C} \mathrm{l}, \mathrm{Pe}, \mathrm{Adm}, \mathrm{Inf}, \mathrm{D}, \mathrm{Udr})
$$

This variant is not analyzed in this article, because it is a significantly wider and more general one. It is de facto the primary task of transportation as a science.

If sustainable development is perceived as a determinate - but, regarding other matters, indispensable - specification of argument $\mathrm{D}$, we can reformulate the relevant degree of the production function:

$$
\mathrm{E}^{\cdots \cdots}=\mathrm{f}^{\cdots} \cdots\left(\operatorname{Inv}, \mathrm{Mat}, \check{\mathrm{C}} \mathrm{l}, \mathrm{Pe}, \mathrm{Adm}, \mathrm{Inf}, \mathrm{D}^{\mathrm{Udr}}\right)
$$

extending the argument $\mathrm{D}^{\mathrm{Udr}}$ into the form:

$$
\mathrm{D}^{\mathrm{Udr}}=\mathrm{f}^{\mathrm{Udr}}(\mathrm{MetD}, \mathrm{UloD}, \mathrm{ParD})
$$


where:

MetD is to be understood as a complex of methods especially for the branch of transportation as a complex of scientific tasks of transportation (vide (Vlček, 1996)), dealing with applications of the principles of sustainable development.

ParD is to be taken as a complex of external parameters, enclosing a summary and spacetime of UloD, of course constrained by the limits of the survival of the Systems (Alliance) as a whole, which are represented just by parameters, by characteristics, by criteria or limits of the sustainable development (that means by the parameters of a quality of the living environment, of a balance of the ecosystem with a coincidental global economy increase - in other words by the conformity of all three linchpins of sustainable development (vide WCED, 1987; ČR, 2006; ČR, 2006).

The goal of the study of synergy effects is "sustainable transportation": methods and processes of searching for optimal strategies of behavior and functions of transportation for both the preservation of development and life (Veselý, 2005). The increased qualitative effect on the System as a whole (Vlček, 1996) can be expected.

\subsection{Reflections of demands on sustainable transportation in actual practices}

The major cross-sectional and multidisciplinary area where the idea of sustainability is reflected is territorial planning. This area of human activity implements, in a summary of its methods, the very substance of a Systems approach to environmental changes - as well as logical and conceptual support for sustainability, not only of its own Systems Identity, but also of a Strategic Identity (Veselý, 2005; Vlček, 1984; Vlček, 1996; Vlček \& Petr, 1983). Territorial planning (WCED, 1987; ČR, 2006; ČR, 2006) is (from the point of view of synergy) simply the area, dealing with Multi -Systems, Hybrid Systems or even with Alliances. Some of the typical tasks are:

- the relation among particular components of territorial planning activities,

- the tackling of complexity, heterogeneity and uncertainty,

- dealing with global, social, human, territorial and artificial components, taking into account human community behavior,

- the optimization of nature resources utilization,

- the solution of technology impacts on the environment,

- linking with modern technologies, economy, environmental activities and social problems.

From this point of view we can envisage territorial planning (WCED, 1987; ČR, 2006; ČR, 2006) (till now understood just as a one-track discipline) as a logical framework, including transportation in a wider sense (Vlček, 1996) as a transfer of material, energy and information / knowledge entities (Vlček, 1999) (e.g., the transfer of life styles, types of residential infrastructures, ideas of environment protection). In such a generalization of territorial planning, it is consequently possible to apply the principles of sustainable development together with technology and civilization progression, as well. Within this context the criteria and limits, resulting from processes such as EIA, SEA etc., are determined (WCED, 1987; ČR, 2006; ČR, 2006). The Systems Identity and conditions for its sustainability are formulated, as well as specific arguments for the formulation of production functions $\mathrm{f}^{\text {"..." }}$. They should illustrate their inherent synergy effects for the solution of transportation tasks with respect to the principles of sustainable 
development. Within this framework geographical information system - GIS (Dale, 2005; ElHamied Hasen, 2000; Haines-Young, 1993; Vlčková, 2009; Vlčková, 2010; Vlčková elaborated text), is characteristic as the sophisticated tool. GIS enables operations with spatial alias geographical data, with spatial - geographical information and consequently it also enables the generation and usage of spatial - geographical knowledge and experience (in the information sense of the word).

GIS can be implemented (Vlčková, 2009; Vlčková, 2010; Vlčková - elaborated text) at four basic application levels:

1. at the first level of a simple display of territory features,

2. at the next level of the modeling of territory features; the fundaments of it lie in generation of derived, transitive spatial information and its projection,

3. at the third level we can speak of the prediction of spatial features,

4. at the last level we have the supreme use of this tool - working within the GIS environment - which means that all solutions of problems, all processes are thoroughly outlined in GIS and they are based on computing, modeling and prediction methods and GIS-tools for the spatial analysis of all data and information.

In this sense it concerns not only the simple processing of "geographical" data, information and knowledge, but more extensive knowledge systems, as well as resulting in complex geographical information and geographical knowledge of environmental characteristics.

\section{THE VISIONS}

To summarize the basic content of the presented considerations the concept of "Synergy Transportation" could be introduced. Transportation, in such a meaning, embodies the attributes of synergy resulting from the basic features of the ternary relation Transportation / Human society / Sustainable Development.

To proceed further on the background of (Veselý, 2005; Vlček, 1996; Vlček, 1999), it is possible to utilize the ideas of theories of catastrophes and chaos and their complements, theories of ordering and self-organization to the analyzing, explaining and predictions of the behavior and emergences in Complex Hybrid Systems and Systems Alliances. The originals to these Systems entities are the wholes of Transportation and Communication, nested within the Human Society and placed on the Earth.

\section{REFERENCES}

Dale, Peter. 2005. Introduction to mathematical techniques used in GIS. CRC Press. Boca Raton . 0-415-33414-4.

El-Hamied Hassen, Tarek Abd. 2000. Implementation of Geographic Information System (GIS) to support urban development analysis for decision making process. $\mathrm{Ph} . \mathrm{D}$. thesis. CTU, FCE. Prague.

EUROPEAN COMMISSION (EC). 2003. European Common Indicators (ECI). Česká verze Společné evropské indikátory udržitelného rozvoje na místní úrovni. AmbienteItalia. http://www. reccr. cz/projektys/indikator/indikator. html, http://www. sustainable-cities. org/expert. html 
Haines-Young, R. H. 1993. Landscape ecology and geographic information systems. CRC Press. London. 0-7484-0002-8.

Mezřický, Václav a kol. 2005. Environmentální politika a udržitelný rozvoj. Portál. Praha. 807367-003-8.

Míchal, Igor. 1976. O odpovědném vztahu k přirodě - předpoklady ekologické etiky. Pražské středisko státní památkové péče a ochrany př́rody. Praha. 80-85368-22-6.

Míchal, Igor. 1994. Ekologická stabilita. Veronica. Brno.

Ř́ha, Josef. 2001. Nový fenomén - posuzování udržitelnosti. Ochrana přírody 56/2, pp. 41-44.

UNITED NATIONS. 1992. The Rio Declaration on Environment and Development. UNO. New York.

UNITED NATIONS - ECONOMIC COUNCIL FOR EUROPE (UN-ECE). 2002. Report from 9th Conference on Urban and Regional Research. HBP/SEM 53/2.

UNITED NATIONS - ECONOMIC COUNCIL FOR EUROPE (UN-ECE). 2002. Sharing.

ÚSTAV ÚZEMNÍHO ROZVOJE. 2000. Principy udržitelného územního rozvoje. ÚÚR. Brno.

Veselý, Jaroslav. 2005. Úvod do systémové strategie dopravy. ČVUT. Praha. 80-01-03184-5.

Vlček, Jaroslav. 1984. Metody systémového inženýrství. SNTL. Praha.

Vlček, Jaroslav. 1996. Doprava jako věda. Doprava předmět vědeckého zkoumání - sborník př́spěvků, kolokvium. Praha.

Vlček, Jaroslav. 1999. Systémové inženýrství. ČVUT. Praha. 80-01-01905-5.

Vlček, Jaroslav, Petr, Jan. 1983. Analýza a projektování systémů. ČVUT. Praha. skripta.

Vlčková, Veronika. 2010. Geoznalost a geoinformační inženýrství. GIS na ČVUT (sborník př́śsp̌vků). ČVUT, ARCDATA. Praha. 978-80-904450-2-4.

Vlčková, Veronika. 2009. Co je GIS (nepublikovaná přednáška).

Vlčková, Veronika. Geoinformační inženýrství (dosud nepublikováno - rozpracovaný text).

Wolf, Paul R. 1997. Adjustment computations: statistics and least squares in surveying and GIS. John Wiley \& Sons. New York, Wiley. 0-471-16833-5.

WORLD COMMISSION ON ENVIRONMENT AND DEVELOPMENT (WCED). 1987. Our Common Future. Oxford University Press. Oxford.

2004. Strategie udržitelného rozvoje České republiky. národní dokumenty ČR. Praha.

2006. Responsibility: Redefining the public interest for territorial development. Draft Report for the Conference on Urban and Regional Research.

2006. Vyhláška MMR č, 500/2006 Sb. , o územně analytických podkladech, územně plánovací dokumentaci a způsobu evidence územně plánovací činnosti. národní dokumenty ČR. Praha.

2006. Zákon č. 183/2006 Sb. , o územním plánování a stavebním řádu (stavební zákon). národní dokumenty ČR. Praha. 